\title{
Pengaruh Dana Pihak Ketiga (DPK), Capital Adequacy Ratio (CAR), Non Performing Financing (NPF) terhadap Likuiditas Bank Umum Syariah (BUS) Periode 2015-2017
}

\author{
Mayvina Surya Mahardhika Utami \& Muslikhati \\ Program Studi Ekonomi Syariah, Fakultas Agama Islam \\ Universitas Muhammadiyah Malang \\ Email: mayvina.mahardhika01@gmail.com
}

\begin{abstract}
This research present to analyze the Third Party Fund (DPK), Capital Adequacy Ratio (CAR), Non Performing Financing (NPF) to liquidity in Islamic Bank as a whole. The period used in this study is 2015 to 2017. This research type and uses an approach to not exist or not based on one or more variables. The variables in this research are Third Party Fund (DPK), Capital Adequacy Ratio (CAR), Non Performing Financing (NPF). While the dependent variable in this research is liquidity at Sharia Commercial Bank. The data used is secondary data from webside BI and OJK, while the data analysis technique is Multiple Regression Analysis. The results of this study indicate that the variable of Third Party Funds (DPK), Capital Adequacy Ratio (CAR), Non Performing Financing (NPF) simultaneously have a significant influence on the level of liquidity. While partially DPK and NPF have a significant influence, whereas CAR has no significant effect.
\end{abstract}

Keywords: Third Party Fund (DPK), Capital Adequacy Ratio, Liquidity, Islamic Bank. 


\begin{abstract}
ABSTRAK
Penelitian ini bertujuan untuk melakukan analisis terhadap Dana Pihak Ketiga (DPK), Capital Adequacy Ratio (CAR), Non Perfoming Financing (NPF) terhadap likuiditas yang ada pada Bank Umum Syariah secara keseluruhan. Periode yang digunakan pada penelitian ini adalah tahun 2015 sampai dengan tahun 2017. Penelitian ini berjenis penelitian kuantitatif dan menggunakan pendekatan korelasi guna menentukan ada atau tidak hubungan pada dua variabel atau lebih. Variabel independen pada penelitian ini adalah Dana Pihak Ketiga (DPK), Capital Adequacy Ratio (CAR), Non Performing Financing (NPF). Sedangkan variabel dependen pada penelitian ini adalah likuiditas pada Bank Umum Syariah. Data yang digunakan adalah data sekunder dari webside BI dan OJK, sedangkan teknik analisis data yang digunakan adalah Analisis Regresi Berganda. Hasil penelitian ini menunjukkan bahwa variabel Dana Pihak Ketiga (DPK), Capital Adequacy Ratio (CAR), dan Non Performing Financing (NPF) secara simultan mempunyai pengaruh yang signifikan terhadap tingkat likuiditas. Sedangkan secara parsial DPK dan NPF mempunyai pengaruh yang signifikan, kemudian CAR tidak berpengaruh secara signifikan.
\end{abstract}

Kata Kunci: Dana Pihak Ketiga, Capital Adequacy Ratio, Likuiditas, Bank Syariah.

\title{
1. Pendahuluan
}

Perbankan syariah merupakan segala sesuatu yang menyangkut tentang bank syariah dan unit usaha syariah, yang mencakup tentang kelembagaan, kegiatan usaha, serta cara dan proses dalam melaksanakan suatu kegiatan usahanya. Fungsi dari Bank Syariah yaitu menghimpun dana dari masyarakat dalam bentuk titipan dan investasi yang berasal dari pihak pemilik dana. Bank Syariah memilki fungsi lain yakni menyalurkan dana kepada pihak lainnya (Ismail, 2014: 32).

Dana Pihak Ketiga merupakan salah satu sumber terbesar yang paling diandalkan oleh bank. Dana Pihak ketiga atau dana yang dihimpun dari masyarakat tersebut terdiri dari beberapa jenis, yaitu: 1) Giro merupakan simpanan dari pihak ketiga atau masyarakat pada bank, dalam penarikannya dapat dilakukan setiap saat dengan menggunakan cek, bilyet giro, dan surat pemerintah pembayaran lainnya atau denga cara lain seperti pemindahbukuan, 2) Deposito atau yang disebut juga simpanan berjangka, merupakan simpanan yang penarikannya dapat dilakukan dalam jangka waktu tertentu sesuai dengan awal perjanjinjiannya, 3) Tabungan adalah simpanan pihak ketiga pada bank yang penarikannya hanya dapat dilakukan menurut syarat-syarat tertentu (Dendawijaya, 
2001: 49-119). Lima tahun terakhir pada perbankan syariah Indonesia mengalami pertumbuhan yang pesat, perubahan tersebut dilihat dari Dana Pihak Ketiga (DPK) yang dihimpun perbankan syariah pada tahun 2010-2015 meningkat yang awalnya dari 204 menjadi Rp 231,2 triliun. Pada saat itu sektor swasta sedang mendominasi penempatan DPK di perbankan syariah sebesar Rp 192 triliun atau dapat dikatakan dalam bentuk persen sekitar 83 persen, sementara pada dana pemerintah hanya mencapai $\mathrm{Rp} 38$ triliun atau setara dengan 16,5 persen (https://databoks.katadata.co.id).

Capital Adequacy Ratio (CAR) adalah rasio permodalan yang berarti dapat menunjukkan suatu kemampuan bank dalam menyediakan dana untuk keperluan pembangunan usaha dan menampung risiko kerugian dana yang dapat diakibatkan oleh kegiatan operasi bank. Semakin tinggi CAR maka semakin besar pula sumber daya finansial yang secara umum digunakan untuk keperluan pembangunan usaha dan mengantisipasi dengan adanya potensi kerugian yang dapat diakibatkan oleh penyaluran pembiayaan (Susilowati, 2016: 8).

Ketahanan permodalan perbankan terus meningkat akibat menurunnya pertumbuhan kredit dan naiknya profitabilitas perbankan. Pada bulan Desember tahun 2015, nilai Capital Adequacy Ratio (CAR) perbankan sebesar 21,5\%. Kemudian pada bulan Desember 2016, nilai tersebut mengalami peningkatan sebesar 1,5\% sehingga menjadi 22,7\%. Level CAR perbankan Indonesia berada jauh di atas rata-rata CAR perbankan di kawasan ASEAN dan peer group (www.bi.go.id). Non Performing Financing (NPF) adalah rasio antara pembiayaan yang bermasalah dengan total pembiayaan yang disalurkan oleh bank syariah. Berdasarkan kriteria yang sudah ditetapkan oleh Bank Indonesia kategori yang termasuk dalam NPF adalah pembiayaan kurang lancar, diragukan dan macet (Arianti NP, 2011).

Bank Umum Syariah pada bulan Februari 2017, NPF mempunyai nilai tertinggi secara nominal yaitu sebesar Rp 6,82 miliar pada akad Murabahah atau setara dengan rasio NPF sebesar 4,9\%. Sementara itu, pada akad Ijarah rasio NPF gross tertinggi yang awal semula pada bulan Februari 2016 sebesar 1,79\% mengalami peningkatan sebesar 5,61\% sehingga pada bulan Februari 2017 nilainya menjadi $7,4 \%$. Pertumbuhan ekonomi yang tinggi dapat dilihat melalui dengan adanya suatu kinerja pada perbankan syariah yang terdiri dari segi NPFnya baik atau buruk. Pertumbuhan sektor riil mengalami sedikit macet pada beberapa tahun terakhir. Sektor pertambangan, komoditas, dan sektor lain yang terkait dengan adanya kemacetan pertumbuhan sektor riil, merupakan penyebab macetnya pertumbuhan sektor riil yang dialami saat ini. Keadaan ini dapat berimbas terhadap kinerja pembiayaan perbankan syariah (http://ekonomi.kompas.com).

Perhitungan rasio likuiditas dengan rasio FDR dapat digunakan untuk mengetahui seberapa jauh bank dapat memenuhi permintaan kredit nasabah, sehingga bank dapat memenuhi kewajibannya untuk memenuhi keinginan 
deposan yang ingin menarik kembali uangnya yang digunakan untuk pembiayaan (Dendawijaya, 2005).

Likuiditas perbankan pada tahun 2016 cenderung tinggi seiring dengan meningkatannya ekspansi keuangan pemerintah sejak awal tahun, pelonggaran Giro Wajib Minimum (GWM) yang dilakukan oleh Bank Indonesia, serta perlambatan pertumbuhan kredit. Peningkatan likuiditas perbankan tercermin dari rasio alat likuiditas terhadap Dana Pihak Ketiga (AL/DPK) yang meningkat dari 19,4\% pada tahun 2015 menjadi 20,9\% pada akhir 2016. Sementara rasio alat likuid terhadap Non Core Deposito (AL/NCD) meningkat dari 93,4\% pada 2015 menjadi $99,4 \%$ pada 2016.

Berdasarkan uraian yang dijelaskan diatas, maka peneliti tertarik dalam melakukan penelitian. Hal ini dapat di sebabkan karena adanya penelitian terdahulu yang membahas tentang likuiditas dengan variabel FDR pada objek perbankan syariah di seluruh Indonesia yang terdiri dari BUS dan UUS, sedangkan peneliti tertarik untuk membahas likuiditas dengan menggunakan variabel Y yaitu Financing to Deposito Ratio (FDR) pada objek Bank Umum Syariah (BUS) karena pada umumnya BUS merupakan lembaga yang berdiri sendiri sedangkan UUS dan BPRS masih dalam naungan konvensional, selain itu agar objek berbeda dengan penelitian terdahulu. Apabila dilihat dari penelitian terdahulu, yang berbeda adalah tidak adanya tinjauan syariah pada penelitian terdahulu.

\section{Tinjauan Pustaka}

\subsection{Dana Pihak Ketiga (DPK)}

Sejak awal kelahirannya, perbankan syariah dilandasi dengan kehadiran dua gerakan renaissance Islam modern: neorevivalis dan modernis. Tujuan utama dari pendirian lembaga keuangan yang berlandaskan etika ini adalah tiada lain sebagai upaya kaum muslimin untuk mendasari segenap aspek kehidupan ekonominya berlandaskan Al-Qur'an dan As-Sunnah (Antonio, 2001: 18).

Di Indonesia, bank syariah yang pertama didirikan pada tahun 1992 adalah Bank Muamalat Indonesia (BMI). Meskipun pada perkembangannya sedikit terlambat bila dibandingkan dengan negara-negara Muslim lainnya, perbankan syariah di Indonesia akan terus berkembang. Bila pada periode tahun 1992-1996 hanya ada satu unit Bank Syariah, maka pada tahun 2005, jumlah bank syariah di Indonesia telah bertambah menjadi 20 unit, yaitu 3 bank umum syariah dan 17 unit usaha syariah. Sementara itu, jumlah Bank Perkreditan Rakyat Syariah (BPRS) hingga tahun 2004 bertambah menjadi 88 buah (Karim, 2004: 25).

Dana pihak ketiga adalah dana yang diperoleh dari masyarakat, yang dimaksud dengan masyarakat dapat diartikan sebagai individu, perusahaan, pemerintah rumah tangga, koperasi, yayasan dan lain-lain baik dalam mata uang rupiah maupun dalam valuta asing. Pada setiap bank yang berperan sebagai 
penghimpun, dana yang diperoleh dari masyarakat merupakan sumber dana terbesar yang paling diandalkan oleh bank.

Dana Pihak Ketiga merupakan dana yang dipercayakan oleh masyarakat kepada bank melalui perjanjian penyimpanan dana dalam bentuk giro, tabungan, dan deposito dengan menggunakan prinsip syariah. Dengan rumus sebagai berikut (Susilowati, 2016: 24)

$$
\text { DPK }=\text { Giro }+ \text { Deposito }+ \text { Tabungan }
$$

Untuk memperoleh sumber dana dari masyarakat luas, bank dapat menawarkan berbagai jenis simpanan. Pembagian jenis simpanan ke dalam beberapa jenis berguna agar para nasabah sebagai penyimpan mempunyai berbagai pilihan sesuai dengan tujuan masing-masing. Tiap masing-masing pilihan mempunyai pertimbangan tertentu dan adanya suatu pengharapan yang ingin diperoleh, seperti keuntungan, kemudahan atau keamanan terhadap uangnya (Kasmir, 2002: 64).

\subsection{Capital Adequacy Ratio (CAR)}

Capital Adequacy Ratio (CAR) adalah rasio untuk mengukur kecukupan modal yang dimiliki oleh bank guna untuk menunjang aktiva yang mengandung atau menghasilkan resiko, misal pembiayaan yang diberikan. Capital Adequacy Ratio (CAR) merupakan rasio yang memperlihatkan seberapa jauh seluruh aktiva bank yang mengandung resiko (pembiayaan, penyertaan, surat berharga, dan tagihan pada bank lain) ikut dibiayai dari dana modal sendiri bank disamping memperoleh dana-dana dari sumber diluar bank, seperti dana masyarakat, pinjaman (hutang) dan lain-lain (Dendawijaya, 2005: 121).

Kekayaan yang dimiliki suatu bank terdiri atas aktiva lancar dan aktiva tetap, kedua aktiva tersebut merupakan penjaminan solvabilitas bank. Dana (modal) digunakan untuk modal kerja dan penjamin likuiditas bank yang bersangkutan. Pada peraturan bank Indonesia Nomor 3/21/PBI/2001, bank wajib menyediakan modal minimum sebesar $8 \%$ untuk dinyatakan sehat dari aktiva tertimbang menurut resiko yang dinyatakan dalam Capital Adequacy Raatio (CAR). Rumus CAR adalah sebagai berikut (Wardiantika \& Kusumaningtyas, 2014) :

$$
\mathrm{CAR}=\frac{\text { Modal }}{\text { ATMR }} \times 100 \%
$$

Konsep teori permodalan pada bank syariah dan konvensional memiliki perbedaan. Pandangan Islam, modal pinjaman (subordinated loan) termasuk dalam kategori qard yaitu pinjaman harta yang diminta kembali. Pada literatur 
fiqh Salaf Ash Shalih, qard dikategorikan dalam akad tathawwu' atau akad saling membantu dan bukan transaksi komersial (Antonio, 1999: 233).

\subsection{Non Performing Financial (NPF)}

Pada bank syariah istilah Non Performing Loan (NPL) diganti dengan Non Performing Finance (NPF) karena dalam bank syariah menggunakan prinsip pembiayaan berbeda dengan bank konvensional yang menggunakan istilah kredit. Rasio ini digunakan untuk mengukur tingkat permasalahan pembiayaan yang dihadapai oleh bank syariah. NPF adalah jumlah pembiayaan yang bermasalah dan kemungkinan tidak dapat ditagih, semakin besar nilai NPF maka akan menjadikan dampak buruk bagi kinerja bank tersebut. Rumus yang digunakan adalah (Zulfiah \& Susilowibowo, 2014: 759-770),

\section{$\mathrm{NPF}=\frac{\text { Jumlah Pembiayaan bermasalah }}{\text { Total Pembiayaan }} \times 100 \%$}

Resiko pembiayaan meningkat, margin atau bunga kredit akan meningkat pula. Dalam perbankan Islam tidak mengenal instrumen bunga karena yang digunakan adalah margin atau bagi hasil itu pada keuntungan ataupun pada kerugian sesuai dengan kesepakatan (Kamal, 2014: 47). Resiko yang terjadi dari pembiayaan atau pinjaman adalah peminjaman yang tertunda atau ketidakmampuan peminjam untuk membayar kewajiban yang telah dibebankan. Untuk mengantisipasi hal tersebut maka bank syariah harus mampu menganalisis penyebab permasalahan (Muhamad, 2002: 267).

\subsection{Rasio Likuiditas}

Menurut Peraturan Bank Indonesia No. 9/1/PBI/2007 tentang Sistem Penilaian Tingkat Kesehatan Bank Umum Berdasarkan Prinsip Syariah, penilaian likuiditas merupakan indikator untuk menilai kemampuan bank dalam memelihara tingkat likuiditas yang memadai termasuk antisipasi atas risiko likuiditas yang akan muncul (Susilowati, 2016: 21). Likuiditas menunjukkan kemampuan suatu perusahaan untuk memenuhi kewajiban keuangannya yang segera harus untuk dipenuhi, atau kemampuan perusahaan untuk memenuhi kewajiban keuangan pada saat ditagih (Munawir, 2007: 31).

Likuiditas perusahaan dapat diukur dan diketahui dengan menggunakan, yaitu diantaranya quick ratio, cash ratio dan Loan to Deposito Ratio (LDR). Loan To Deposito Ratio (LDR) atau Financing to Deposito Ratio (FDR) adalah perbandingan antara total pembiayaan yang diberikan terhadap total dana pihak ketiga yang dihimpun (Dendawijaya, 2003: 59).

Financing to Deposito Ratio (FDR) menyatakan kemampuan bank dalam membayar kembali penarikan dana yang dilakukan deposan dengan mengandalkan pembiayaan yang diberikan sebagai sumber likuiditasnya, atau 
dengan kata lain seberapa jauh pemberian pembiayaa kepada nasabah dapat mengimbangi kewajiban bank untuk segera memenuhi permintaan deposan yang akan menarik kembali dananya yang telah disalurkan oleh bank berupa pembiayaan. Semakin tinggi rasio tersebut memberikan indikasi rendahnya kemampuan likuiditas bank yang bersangkutan (Suwiknyo, 2010: 148).

Rumus menghitung FDR adalah sebagai berikut:

$$
F D R=\frac{\text { Total Pembiayaan }}{\text { Total Dana Pihak Ketiga }} \times 100 \%
$$

\section{Metode Penelitian}

Jenis penelitian yang digunakan adalah deskriptif kuantitatif yaitu metode analisa data dengan menggunakan data dalam bentuk angka-angka atau nilai dari bentuk data kemudian dianalisa dengan menambahkan keterangan berupa kalimatkalimat untuk menerangkan data kuantitatif (Kuncoro, 2013: 14). Populasi (objek) yang digunakan pada penelitian ini adalah seluruh Bank Syariah yang ada di Indonesia yang terdiri dari Bank Umum Syariah (BUS), Unit Usaha Syariah (UUS), dan Bank Pengkreditan Rakyat Syariah (BPRS) sedangkan pada penelitian ini sampel yang diambil adalah data secara keseluruhan Bank Umum Syariah (BUS) yang terdaftar dalam Bank Indonesia.

Data yang digunakan dalam penelitian ini merupakan data sekunder, yang berupa data runtun waktu (time series) dengan skala bulanan. Data tersebut dapat diambil dari histori Dana Pihak Ketiga (DPK), Capital Adequacy Ratio (CAR), Non Performing Financing (NPF) dan Likuiditas pada website (www.ojk.go.id) yang diperoleh dari laporan kegiatan usaha Bank Umum Syariah (BUS) secara keseluruhan dengan rentang waktu yang sama pada periode 2015-2017.

Dalam penelitian ini akan digunakan model regresi linier berganda karena memiliki variabel penduga lebih dari satu yaitu $\mathrm{X}_{1}$ sampai Xn (Kuncoro, 2013: 39). Adapun model regresi yang digunakan adalah sebagai berikut:

$\mathrm{Y}=\alpha+b_{1} x_{1}+b_{2} x_{2}+b_{3} x_{3}+b_{4} x_{4}+e$

Keterangan :

$\mathrm{Y}=\mathrm{FDR}$

$X_{1}=$ Dana Pihak Ketiga (DPK)

$\mathrm{X}_{2}=$ Capital Adequacy Ratio (CAR)

$X_{3}=$ Non Performing Financing (NPF)

$b=$ Koefisien Regresi

$e=$ Standard Error 


\section{Pengaruh Dana Pihak Ketiga (DPK) terhadap Likuiditas(FDR)}

Berdasarkan hasil pengujian secara parsial, variabel DPK menunjukkan hasil berpengaruh signifikan tetapi memiliki hubungan yang negatif terhadap likuiditas (FDR) yang ditunjukkan dengan nilai t hitung sebesar 9,930 dengan tingkat signifikansi sebesar 0,000 serta t tabel sebesar 1.69552. Karena nilai signifikansi < dari 0,05 dan nilai $\mathrm{t}_{\text {hitung }} \mathrm{t}_{\text {tabel }}$ maka dapat disimpulkan bahwa Dana Pihak Ketiga (DPK) berpengaruh secara parsial terhadap likuiditas (FDR). Sehingga hipotesis yang diajukan yaitu Hol ditolak dan Ha1 diterima.

Variabel CAR menunjukkan hasil tidak berpengaruh signifikan dan memiliki hubungan yang negatif terhadap FDR yang ditunjukkan dengan nilai $t$ hitung sebesar 1,283 dengan tingkat signifikansi sebesar 0,209 serta t tabel sebesar 1.69552. Karena nilai signifikansi > dari 0,05 dan $\mathrm{t}_{\text {hitung }} \mathrm{t}_{\text {tabel }}$ maka dapat disimpulkan bahwa Capital Adequacy Ratio (CAR) tidak berpengaruh secara parsial terhadap likuiditas(FDR). Sehingga hipotesis yang diajukan yaitu $\mathrm{H}^{\mathrm{o}} 2$ diterima dan $\mathrm{H}^{\mathrm{a}} 2$ ditolak.

\section{Tabel 1.1}

Uji T

\begin{tabular}{ccccc}
\hline Variabel & t hitung & Sig. & t tabel & Keterangan \\
\hline DPK $(X 1)$ & $-9,930$ & 0,000 & 1,69552 & Signifikan \\
\hline CAR $(X 2)$ & $-1,283$ & 0,209 & 1,69552 & Signifikan \\
\hline NPF $(X 3)$ & $-2,787$ & 0,009 & 1,69552 & Signifikan \\
\hline
\end{tabular}

Variable NPF menunjukkan hasil berpengaruh signifikan tetapi memiliki hubungan negatif terhadap FDR yang ditunjukkan dengan nilai t hitung sebesar 2,787 dengan tingkat signifikansi 0,009 serta $t$ tabel 1.69552. Karena nilai signifikansi sebesar $<$ dari 0,05 dan nilai $t_{\text {hitung }}>t_{\text {tabel }}$ maka dapat disimpulkan bahwa Non Performing Financing (NPF) berpengaruh secara parsial terhadap likuiditas (FDR). Sehingga hipotesis yang diajukan yaitu Ho3 ditolak dan Ha3 diterima.

Hasil penelitian ini mendukung hasil penelitian yang dilakukan oleh Susilowati (2016) bahwa Dana Pihak Ketiga (DPK) berpengaruh signifikan terhadap likuiditas (FDR) dan pada penelitian Ardiansari (2017) dan Fikriati (2015) menunjukkan Dana Pihak Ketiga (DPK) berpengaruh negatif dan signifikan terhadap likuiditas (FDR). Hasil penelitian, peneliti mendapatkan hasil bahwa Dana Pihak Ketiga (DPK) berpengaruh negatif dan signifikan terhadap Financing to Depost Ratio (FDR). Secara teori, semakin besar DPK membuat rasio FDR menurun. Hal ini terjadi karena likuiditas bank syariah meningkat setelah bertambahnya DPK. 
Pada Variabel Capital Adequacy Ratio (CAR) terdapat pengaruh negatif dan tidak signifikan terhadap Financing ti Deposit Ratio (FDR). Adanya hasil penelitian ini mendukung dari hasil penelitian yang telah di kemukakan oleh Susilowati (2016). Berdasarkan pengertian tentang FDR dinyatakan bahwa seberapa jauh kemampuan bank dalam membayar kembali penarikan dana yang dilakukan oleh deposan dengan mengandalkan pembiayaan yang diberikan sebagai sumber likuiditasnya. Dengan hal ini dapat dilihat hubungan FDR dengan CAR yaitu saat FDR tinggi yang disebabkan pembiayaan tinggi sedangkan dana yang dihimpun sedikit dapat menyebabkan CAR menurun, dengan asumsi CAR digunakan untuk menutupi kekurangan dana tersebut.

Sementara berdasarkan hasil tabel 4.10, variabel Non Performing Financing (NPF) memiliki nilai signifikansi $0,009<0,05$. Hal ini maka menerima $\mathrm{H}^{\mathrm{a}}$ atau menolah $\mathrm{H}^{\mathrm{o}}$, sehingga dapat disimpulkan bahwa variabel NPF secara parsial berpengaruh terhadap likuiditas (FDR). Hasil penilitan ini mendukung hasil penelitian yang telah dilakukan oleh Prihatiningsih (2012) bahwa NPF berpengaruh signifikan terhadap likuiditas (FDR). Hal ini dapat diketahui pula bahwa perubahan-perubahan tingkat variabel NPF memiliki hubungan yang negatif terhadap tingkat Financing to Deposit Ratio (FDR) pada Bank Umum Syariah. Hasil penelitian ini mendukung hasil penelitian yang telah dilakukan oleh Fikriati (2015) bahwa NPF mempunyai pengaruh negatif terhadap likuiditas (FDR) dan pada penelitian Susilowati (2016) menunjukkan bahwa NPF berpengaruh negatif dan signifikan terhadap likuiditas (FDR).

Pada hasil analisis secara parsial menunjukkan koefisien yang negatif sehingga sesuai dengan teori yaitu menunjukkan pengaruh yang negatif terhadap FDR. Semakin tinggi rasio FDR menandakan semakin rendah kemampuan likuiditas bank tersebut, karena FDR yang terlampau tinggi menunjukan jumlah DPK yang tidak mampu menutupi pembiayaan yang disalurkan (Muhammad, 2002: 311).

\section{Tabel 1.2}

Uji F

\begin{tabular}{cccc}
\hline F hitung & Sig. & F tabel & Keterangan \\
\hline 177,390 & 0,000 & 2,90 & $\begin{array}{c}\text { Berpengaruh } \\
\text { secara simultan }\end{array}$ \\
\hline
\end{tabular}

Berdasarkan uji anova pengujian hipotesis dengan menggunakan uji $\mathrm{F}$ nilai $\mathrm{F}_{\text {hitung }}$ diperoleh sebesar 177,390 dengan signifikansi sebesar 0,000, lalu $\mathrm{F}_{\text {tabel }}$ dengan menggunakan keyakinan sebasar 95\% $(\alpha=0,05)$, df 1 (jumlah variabel-1) atau (4-1=3) dan df2 (n-k) atau (36-4)=32 (n adalah jumlah data dan $\mathrm{k}$ adalah variabel independen). Maka hasil yang didapatkan oleh $F F_{\text {tabel }(3 ; 32)}$ adalah 2,90. Maka dapat diketahui bahwa $F_{\text {hitung }}>F_{\text {tabel }}$ yaitu sebesar 2,90 
sehingga > f tabel $(77,390>2,90)$ maka hipotesis diterima yang menyatakan bahwa variabel bebas secara simultan (bersama-sama) berpengaruh terhadap likuiditas (FDR).

\section{Kesimpulan}

Berdasarkan hasil penelitian dapat disimpulkan bahwa variabel Dana Pihak Ketiga (DPK) dan Non Performing Financing (NPF) secara Parsial berpengaruh signifikan terhadap tingkat likuiditas (FDR) pada Bank Umum Syariah (BUS), sedangkan Capital Adequacy Ratio (CAR) secara Parsial tidak berpengaruh signifikan terhadap tingkat likuiditas (FDR) pada Bank Umum Syariah (BUS). Secara Simultan atau bersama-sama variabel Dana Pihak Ketiga (DPK), Capital Adequacy Ratio (CAR), Non Performing Financing (NPF) mempunyai pengaruh yang signifikan terhadap tingkat likuiditas (FDR) pada Bank Umum Syariah (BUS).

Dengan adanya penelitian ini, diharapkan pihak perbankan syariah untuk terus meningkatkan kinerja terutama pada saat adanya kemungkinan buruk seperti halnya pada Capital Adequacy Ratio (CAR) yang disebut dengan rasio permodalan dan pembiayaan bermasalah, untuk memungkinkan supaya tidak mengganggu kegiatan operasional pada perbankan syariah dan pada penyaluran pembiayaan tetap dapat berjalan dengan lancar. Penelitian selanjutnya dapat menambahkan variabel lainnya seperti inflasi, Return On Aset (ROA), BOPO, dan faktor eksternal lainnya yang terdapat pada perbankan syariah.

\section{Daftar Pustaka}

Antonio, Muhammad Syafi'i. (1999). Bank Syariah. Wacana Utama dan Cendekiawan. Jakarta: Diterbitkan atas kerja sama BI dengan Tazkia Institute.

Jakarta: Gema Insani Press.

(2001). Bank Syariah: Dari Teori Ke Praktik.

Dendawijaya, Lukman. (2001). Manajemen Perbankan. Jakarta: Ghalia Indonesia. . (2005). Manajemen Perbankan. Jakarta: Ghalia Indonesia. . (2003). Manajemen Perbankan. Bogor: Ghalia Indonesia,

Edisi Kedua.

Husain, Saddan. (2015). "Metafora Amanah Pengelolaan dana Pihak Ketiga (DPK) sebagai Penompang Asset Perbankan Syariah Ditinjau dari Aspek Trilogi Akuntabilitas (Studi Kasus Pada PT. bank BNI Syariah Cabang Makassar)" (Jurnal Iqtisaduna Vol. 1(2).

Hugraheni, E. (2015). Analisis Pengaruh Capital Adequacy Ratio (CAR), Financing to Deposit Ratio (FDR), Beban Operasional-Pendapatan Operasional (BOPO) dan Non Performing Financing (BPF) terhadap Return On Asset (ROA) pada PT. Bank Syariah Mandiri (Doctoral dissertation, Program Pasca sarjana UIN-SU).

Ismail. (2014). Perbankan Syariah. Jakarta: Kencana. 
Kamal, Rendy. (2014). Analisis Pengaruh Non Performing Financing (NPF), Biaya Operasional Terhadap Pendapatan Operasional (BOPO), Capital Adequacy Ratio (CAR) Dan Sertifikat Bank Indonesia Syariah (SBIS) Terhadap Laba Perbankan Syariah Di Indonesia Periode September 2009Desember 2013. Skripsi Ilmu Ekonomi Dan pembangunan UIN Syarif Hidayatullah, Jakarta.

Karim, Adiwarman A. (2004). Bank Islam: Analisis Fiqih dan Keuangan Jakarta: PT RajaGrafindo Persada.

Kasmir. (2002). Dasar-Dasar Perbankan. Jakarta: PT. RajaGrafindo Persada.

Kuncoro,Mudrajad. (2013). Metode Riset Untuk Bisnis \& Ekonomi. Jakarta: Penerbit Erlangga.

Munawir. 2007. Analisis Laporan Keuangan . Yogyakarta: Liberty.

Muhamad. (2002). Manajemen Bank Syariah. Yogyakarta: Unit Penerbit dan Percetakan (UPP) AMPYKPN.

Pratami, Wuri Arianti Novi. (2011). Analisis Pengaruh Dana Pihak Ketiga (DPK), Capital Adequacy Ratio (CAR), Non Performing Financing (NPF) dan Return On Asset (ROA) terhadap Pembiayaan Pada Perbankan Syariah. Studi Kasus Pada Bank Muamalat Indonesia Periode 2001-2011. Universitas Diponegoro.

Rahman, Afzalur. 2005. Doktrin Ekonomi Islam jilid 1. Jakarta: PT. Dana Bankti Waqaf.

Susilowati, Enny. (2016). Pengaruh Dana Pihak Ketiga (DPK), Capital Adequacy Ratio (CAR), dan Non Performing Financing (NPF) Terhadap Likuiditas Perbankan Syariah di Indonesia Periode 2011-2015. Skripsi Universitas Islam Negeri Syarif Hidayatullah, Jakarta.

Suwiknyo, Dwi. (2010). Analisis Laporan Keuangan Perbankan Syariah. Yogyakarta: Pustaka Belajar.

Wardiantika, Lifstin, dan Rachmawati Kusumaningtyas. (2014). Pengaruh DPK, NPF, dan SWBI Terhadap Pembiayaan Murabahah Pada Bank Umum Syariah Tahun 2008-2012. Jurnal Ilmu Manajemen (JIM) 2(4).

Zulfiah, Fitri, and Joni Susilowibowo. (2014). Pengaruh Inflasi, BI Rate, Capital Adequacy Ratio (CAR), Non Performing Finance (NPF), Biaya Operasional dan Pendapatan Operasional (BOPO) Terhadap Profitabilitas Bank Umum Syariah Periode 2008-2012. Jurnal Ilmu Manajemen, Vol. 2, No. 3.

Ini Alasan Pembiayaan Macet Perbankan Syariah Cukup Tinggi, diakses pada tanggal 11 Februari 2018 dari http://ekonomi.kompas.com

Perkembangan DPK Perbankan Syariah 2010-2015, diakses pada tanggal 6 Maret 2018 dari https://databoks.katadata.co.id/datapublish/2016/09/01/perkembangan-dpkperbankan-syariah-2010-2015.htm

Stabilitas sistem keuangan, diakses pada tanggal 09 Februari 2018 dari www.bi.go.id 